\title{
What's obstructing climate change adaptation in environmental water management?
}

Meegan Judd, Centre for Freshwater Ecosystems, La Trobe University, Wodonga meegan.judd@latrobe.edu.au Martina Boese, School of Humanities and Social Sciences, La Trobe University, Bundoora, M.Boese@latrobe.edu.au Avril C. Horne, Department of Engineering, University of Melbourne, avril.horne@unimelb.edu.au Nicholas Bond, Centre for Freshwater Ecosystems, La Trobe University, Wodonga, N.Bond@latrobe.edu.au

This paper is a non-peer reviewed preprint submitted to EarthArXiv.

The paper has been submitted to Ecology and Society 


\title{
What's obstructing climate change adaptation in environmental water management?
}

\author{
Meegan Judd ${ }^{a}$, Martina Boese ${ }^{b}$, Avril C. Horne ${ }^{c}$, Nicholas Bond $^{a}$ \\ a Centre for Freshwater Ecosystems, La Trobe University, Wodonga \\ $b$ School of Humanities and Social Sciences, La Trobe University, Bundoora \\ c Department of Engineering, University of Melbourne
}

\begin{abstract}
Climate change is irreversibly changing the water cycle, yet existing environmental flow assessment methods often fail to recognise the non stationarity of hydro climatic systems. Failure to do so will lead to the inability of environmental water management to achieve its restoration targets. Australia has undergone major reform over the past twelve years to recover water from consumptive use for environmental benefit. This paper examines how government agencies responsible for the planning and delivery of that environmental water establish ecological objectives, whether climate change adaptations are considered important, and if not whether there is a clear rationale or barrier to adaptation. We used semi structured interviews and an online survey of staff involved in environmental water management throughout Australia, with a focus on south east Australia, to gather information on methods and perceptions regarding these key issues. The results show water management staff are aware of the general impacts climate change will have on local areas they are responsible for. However, they do not have the necessary, detailed information about how ecosystems are likely to respond to climate change to plan with confidence. There is also a lack of legislative and policy guidance as to how to deal with the potential inability to meet existing environmental targets. We conclude that environmental water planning needs to more formally incorporate climate change considerations along with modelling approaches that can evaluate outcomes under a range of possible future hydro climatic scenarios. As the industry currently exists in Australia, it is ill prepared for the challenge of meeting legislated ecological targets under future climates.
\end{abstract}

\section{Introduction}

Regulation of rivers by large dams has greatly altered flow regimes globally with significant consequences for riverine and floodplain ecosystems (Knouft and Ficklin 2017, Rolls and Bond 2017). Environmental water plays an important role in restoring such ecosystems in both regulated and unregulated rivers (Arthington et al. 2018). However, climate change presents a new challenge as temperature and rainfall pattern changes alter the volume and timing of runoff. Predicted increased evaporation rates due to higher temperatures and lower soil moisture will add stress to already stressed river systems (Palmer et al. 2008, Saft et al. 2016). As ecosystems respond to changes in climate and hydrologic cycles, managers and policy makers will be forced to consider the implications for existing objectives and targets. Many ecological objectives for environmental water are unlikely to be achievable in a changing climate (Dunlop et al. 2013, Capon and Capon 2017, Judd et al. in prep).

Potential management adaptations to assist aquatic species in a changing climate include increasing landscape connectivity to permit movement to more tolerable habitats, protecting or creating local refuges/habitats within the broader landscape, reallocating water use to offset the flow reductions due to climate change, establishing land easements, and focussing on ecosystem function rather than protecting specific species (West et al. 2009). Evaluating and implementing these various solutions will involve considerable planning and foresight. A number of frameworks have been developed within the natural resources management sector to explore and identify effective and potentially ineffective management responses to climate change (for example the Resist-Accept-Direct framework (Lynch et al. 2021)), however such frameworks are yet to be routinely applied in the context of environmental water management.

This paper uses south east Australia as a case study to investigate the attitudes of environmental water managers to climate change, and whether they identify certain factors as important in limiting and/or enabling their ability to include climate adaptations in management and planning. Without a clear understanding of the 
barriers water managers face, it will be difficult for the industry to move forward. The outcomes of this paper have implications for future environmental flow assessment methods, water planning, and for water policy and legislation.

\section{Case study - south east Australian environmental water managers}

The focus for our work is south east Australia, which spans parts of the Murray Darling Basin and several coastal catchments. The region has complex historical and contemporary water management arrangements and issues, particularly in rivers crossing state jurisdictional boundaries (Hart et al. 2021). Water management includes multiple tiers of government (Figure 1).

Environmental water allocation occurs in two ways; one is through 'passive management' where dam operators are legislated to 'leave' a certain amount of water in the river for environmental benefit (Doolan et al. 2017). The second method is to establish a reserve of water that has the same legal arrangements as consumptive water. This type of water is called an 'entitlement' (O'Donnell 2017). Environmental water entitlements require active management in terms of delivery location, timing and quantity and are only available in regulated rivers (Doolan et al. 2017). Entitlements are of a specified volume which is subsequently allocated water on an annual basis depending on annual inflows to dams. The percentage of allocation varies each year depending on water availability. In times of drought annual water allocations have been as low as zero or thirty percent (Department of Environment 2016).

There have been numerous technical studies examining the likely impacts of climate change on water availability across south east Australia (Chiew et al. 2009, BOM and CSIRO 2015, Clarke et al. 2019, Department of Environment et al. 2020). Local studies suggest cool season rainfall has already declined by $12 \%$ since 1997 (to 2018) compared to 1900-1959 and rainfall runoff relationships have altered (Saft et al. 2016, Rauniyar and Power 2020). Future projections suggest continued decline in cool season rainfall by $1-$ $26 \%$ by 2040 with run off expected to decrease by 5- $40 \%$ (Department of Environment et al. 2020). This decrease in run off will impact water managers annual allocations and ability to achieve ecological targets. While there is significant information available on climate change implications across Australia, this has not translated into environmental water planning (Capon and Capon 2017, Judd et al. in prep).

\section{Method}

Two methods of data collection were employed in this research. First, semi structured interviews were conducted to collect qualitative data from environmental water staff regarding their current and future planning. Interviews were conducted in an exploratory manner using a mix of closed and open ended questions, which enabled us to identify the variety of influences on long term planning for environmental water. Based on the data collected from the interviews, an online survey was developed to expand the sample size and geographic spread, and to test some of the findings from the interviews.

\section{$\underline{\text { Interviews }}$}

We conducted 18 semi structured interviews (Nov-Dec 2020) with water managers from Victoria (State government and regional authorities), New South Wales (State government-regional representative) and Australian Capital Territory (Commonwealth government) representing eleven organisations. Most participants were working in Victoria (13) with two in NSW and three in ACT. All participants have been working in environmental water management between 5 and 30 years, with the most common length of experience between $12-14$ years. The interviewees consisted of five at director/manager level and 13 at officers/coordinator level. Almost all participants had a range of strategic and operational tasks in their role, with two specifically working in an operational capacity only. Interview participants were recruited through professional working groups coordinated by state or commonwealth agencies, using purposive sampling. Additionally, the primary researcher and first author is a practitioner in the field and had privileged access to potential participants through professional networks.

The semi structured nature of the interviews encouraged the natural flow of conversation, while allowing probing for additional content (DeJonckheere and Vaughn 2019). This interview style ensured that key questions were covered across all interviews while allowing for discovery of unexpected factors and gaining a 
better understanding of the perspectives of participants. Interviews ranged in length from 55 to 105 minutes and were conducted, and recorded, via videoconferencing (Zoom video communications). The interview guide consisted of 33 interview questions and is provided in Appendix 1. The interview data helped inform the development of questions for the online survey. Any quotes included in this paper may have been slightly edited for grammatical correctness and clarity. All participants have been de-identified.

\section{Online survey}

An online survey was developed to test and expand on the findings of the interviews. The survey consisted of 30 questions (Appendix 2). The survey was distributed by email invitation to 110 people associated with environmental water management organisations throughout Australia, and recipients were encouraged to further distribute the survey throughout their relevant networks. The survey was open for one month during March/April 2021.

There were 32 completed responses to the survey, with an additional 10 incomplete responses (i.e. where participants did not reach the end of the survey). Incomplete surveys were not included in the data analysis. Responses to the survey were heavily skewed towards Victorian organisations representing 16 (50\%) of the responses. A further four (13\%) came from the ACT, with three each from South Australia and New South Wales, and two each from Western Australia, Queensland and Northern Territory. All responses were from representatives of government agencies except two; one from a not for profit organisation and one from a Traditional Owner group. All responses were anonymous.

\section{Data analysis}

All interviews were transcribed and NVivo 12 Plus (QSR International) was used to analyse the transcripts. Data was coded based on the research question topics, complemented by themes that emerged while analysing the interviews. The online survey data was downloaded into excel spreadsheets and analysed based on themes arising from the interview data and any additional themes that came from the survey. The data analysis included assessment of results from questions employing Likert scales, open and closed questions, and theme analysis linked to the research question. In the data analysis, we have combined the interview and survey results where appropriate and specified which method the results are derived from when not combined.

\section{Limitations of method and data}

The selected methods and collected data have two limitations. The data gained was from a small, purposive sample and cannot be generalised to the entire population of water policy managers (Walter 2006). A limitation of the online survey is the lack of opportunity to request clarifications or add explanations. The uneven representation of different state representatives in the interviews and survey also mean the data is skewed towards Victorian policy makers and practitioners. However, the qualitative approach of the interviews allowed for exploration of the rationales and influences in decision making, which can inform future research with a larger sample.

\section{Results}

Finding 1 - environmental water managers have a strong awareness of climate change issues In the interviews we asked participants to rank their level of concern about a set of specific climate change impacts extracted from the literature. Based on the responses, we included a survey question for participants to also rank their level of concern around these issues. Results show environmental water managers rank many issues of high concern (Figure 2).

There were some differences in degree and object of concern between interview and survey participants, but in both groups the highest concern was around more frequent and longer droughts, and related to this, high concern around competition for water, water availability and reduced run off. Survey responses showed a lower degree of concern for reduced floodplain inundation. This could be related to interviews being conducted primarily with those working in the Murray Darling Basin where floodplain and wetland inundation is a major focus and of broader concern to the community (Tonkin et al. 2008, Rogers 2010, Gell et al. 2019). 
To elicit awareness of predicted changes we asked interview participants an open ended question regarding their perspective on how climate change will impact the area they manage. Their answers showed a thorough awareness of the impacts that climate change will have on their local catchments and generated a list of qualitative, comprehensive changes and implications for hydrology, ecology, water use and resource management, and socio economic factors. However, the following consequences of climate change to general catchment management were also noted by participants and highlights their awareness that climate change impacts will affect more than ecological outcomes (Table 1).

Additionally, the online survey asked if participants specifically incorporated climate change considerations in their decision making or planning of environmental water in their current role (Table 2).

These findings suggest environmental water staff were cognisant of the need to consider climate change, with almost half (46\%) the survey respondents regularly incorporating climate change considerations in their management. It is not clear if this incorporation is in the operational or strategic part of their roles. It should be noted that participation in this research was voluntary and it is likely that participants are environmental water staff interested in climate change, and therefore likely to skew results to higher climate change awareness than the entire population of environmental water staff.

\section{Finding 2 - high organisational support for climate change is not conveyed to environmental water} management

While environmental water staff consider climate change in their planning, interview and survey responses show climate change is considered less of an issue specifically for environmental water management than the organisation as a whole (Figure 3).

The reasons respondents indicated for this discrepancy included:

- Climate change is not adequately addressed in environmental water policy or legislation

- Tools for long term environmental water management do not accommodate inclusion of climate change with many planning documents based on historical data

- Uncertainty regarding quantification of the impacts on environmental water

- The ecological response to flow restoration is slow and political pressure to incorporate climate change is not high (compared to the need to supply consumptive or urban water)

- The industry is not ready to think about it yet. One interview participant commented that:

"I think we've been really focused on just getting environmental water up and going, and into existence, and probably now we're starting to be able to have the freedom to think a bit more broadly about it as an industry"

Finding 3 - flow assessment methods used in south east Australia do not consider climate change Setting ecological objectives for environmental water is predominately undertaken using a specified flow assessment process. Interview results show most organisations in south east Australia have adopted methodologies that are developed and endorsed at a state level (e.g. FLOWS method in Victoria, Basin Plan requirements in NSW). Using these predominately holistic methods, a range of issues are considered when setting objectives, with input provided primarily through independent expert scientific panels, government employed scientists or engineers, and interested community representatives.

The environmental flow assessment methodologies rely on contemporary ecological values, which in turn are based on historic reference states (to varying degrees), protecting or restoring populations of threatened species, and restoring pre development hydrology (Figure 4). There is an absence of consideration of prospective issues such as future streamflow and ecological response to climate change (Judd et al. in prep). Some interview participants acknowledged the flow assessment methods currently employed are not very good at including climate considerations and setting ecological objectives for future environmental conditions, as one participant stated:

"if you're setting objectives based around your historical flows, you're just setting yourself up for failure"

Another interviewee noted the following: 
"The environmental response was based on historical studies, so it doesn't include a future where the area is two degrees hotter and environmental water needs are different to what they've been historically."

Of the eleven organisations represented in interviews, five gave some consideration to future water availability when setting objectives. Most were cursory considerations and did not involve future climate or hydrological modelling. Subsequently, just one organisation changed their ecological objectives by increasing the flexibility of when water could be delivered in acknowledgement of changing rainfall seasonality. Reasons given for not altering objectives included sites requiring only small irregular volumes of water, fear of losing water entitlements, and fear of community backlash if consumptive water recovered for the environment does not achieved the stated objectives.

The following reasons were provided by interview representatives of the six organisations who did not consider future water availability or ecological change:

Lack of information

- not enough information, including hydrological extremes i.e. how to turn changes of hotter temperatures, flashier storms and longer droughts into daily flow simulations

- locally relevant information and methods for incorporating information is only just becoming available

Not knowing how to use the information

- not knowing which climate scenario to plan for

- infancy of the industry where climate change is only just beginning to be deliberated

Other

- plans are reviewed regularly enough to allow adaptive adjustments

- political pressure to keep methods for environmental water recovery as they are

\section{Finding 4 - barriers to climate change adaptation in environmental water management are}

\section{common}

Both the interview and survey specifically asked participants about barriers to the inclusion of climate change considerations (Figure 5). The most common general barriers include 'insufficient funding and staff resources', 'uncertainty around ecosystem response to climate change', 'lack of political leadership' and 'legacy land use and water sharing issues' (note: not all questions were asked in both interview and survey).

Other barriers that were mentioned during interviews included:

- inadequate communication from environmental water organisations to gain legitimacy and community support

- lack of community support for alternate water use e.g. recycled water

- too much emphasis on local outcomes rather than outcomes at a landscape level

- lack of monitoring for adaptive management

A common response in the interview and survey data was a lack of information on streamflow and ecological change. Participants suggested their organisations felt unable to make decisions on climate adaptation while there is such high uncertainty. The survey explicitly asked participants to rank their agreement on whether there is ample information on ecological response to climate change. Twenty two of the 32 respondents either disagreed or strongly disagreed with this statement. Although the interview did not specifically ask this question, data analysis suggests 12 (from 18) respondents disagree with this statement. The following statements from two interviews show these concerns:

"there's a high uncertainty about what the future climate looks like and hence, high uncertainty around what the most appropriate flow regime and flow priorities should be in the future, so what do you do?"

"Even now I don't think we would have enough information and knowledge to be able to confidently make changes to the objectives and targets based on what we know right now." 


\section{Finding 5 - environmental water management faces specific knowledge gaps}

A common theme in the data was knowledge gaps and institutional changes that could better enable inclusion of climate change. Many of the themes raised link as solutions to the barriers outlined in Finding 4 . The desire for improved knowledge exchange and research included topics such as ecological response to climate change including quantified ecosystem response models and tipping points, species/community vulnerability assessments, flow assessment methods that incorporate future climate and hydrological scenarios agreed on by all levels of government, improved knowledge on drought refuge needs (e.g. quantity and spatial spread) and a framework to guide decision making under uncertain circumstances (which also includes socio-economic issues). Other suggestions to address knowledge gaps and overcome the barriers identified in this research are suggested (Table 3 ).

\section{Discussion}

The results from this study suggest environmental water staff show high concern and awareness of climate change impacts. Yet the environmental water industry in Australia is in its infancy and grappling with a backward looking world view where most planning involves reference to observed past stream flows. The slow ecological response rates to flow restoration may mean there is less urgency than in other areas of climate adaptation. The results show there is an underestimation of the importance environmental water can have to adapting freshwater and estuarine environments to climate change.

While the small sample size and relatively uneven spatial coverage make it difficult to widely extrapolate these findings, there were many common issues raised that are likely relevant to the industry more broadly. This study could be expanded, both within Australia and internationally, to determine if the same issues are widespread throughout the industry.

This research shows a lack of government commitment for updating legislation, policies, and guidance to include climate adaptations into long term planning. It is unclear if this lack of commitment comes from a scarcity of funding for the program, a lack of knowledge and understanding of the hydrological and ecological response to climate change, or a political aim to maintain electoral votes for major water reform undertaken in the past twelve years.

Interviews indicated that most existing ecological objectives have been set based on established environmental flow assessment methods most of which do not require consideration of future climate change, and in fact use historical flow regimes as the basis for assessment. Even when lower water availability was considered, objectives were not altered for fear of community backlash if existing objectives were deemed unattainable. This suggests environmental water staff not only feel pressure to deliver water for ecological outcomes, but also feel they need to gain acceptance and legitimacy for the use of environmental water by local communities. This in turn may result in political pressure to show the stated ecological objectives can be achieved, and a fear from water staff to modify ecological objectives in light of a changing climate and reduced water availability - whether this be by removing some restoration targets or altering the type of outcome that is sort. This community and political pressure may lead to environmental water use targeted at short term gains rather than achieving long term outcomes.

Many participants showed high awareness of climate change risks, expressed frustration that environmental flow assessment methods lack consideration of climate change, and suggested more investment is required to incorporate the development of future flow and ecological response scenarios. The lack of guidance for flow assessment methods to incorporate climate change also has implications for consistency of approach with some organisations "going their own way" due to a lack of policy guidance, as one interview participant articulates:

"There's no policy, little science. In the meantime, we've tried to address that science. There's still no policy, so we just keep on plugging away and it seems to be going the right way."

Effective restoration needs well defined objectives and targets, usually determined in collaboration with independent scientific, government and community input. Yet more than half the participants in this study believed their current environmental water objectives will be unachievable in the future. There is concern for 
the 'ability of the environment to sustain the existing values' and concern for 'ecosystem transition to a new state'. Some interviewees believed the ecosystems will change anyway and we need to support the shift, while others were not sure whether to assist with transition or manage for the past. As one interviewee questioned:

"What are we actually trying to achieve? Are things going to change so much that we need to facilitate movement or enable these areas to adapt and change? Or are we trying to keep museums of what used to be? And I'm not going to answer that, but it's a fundamental question in all of this, what decisions are we making and why and what are we achieving by making them?"

Interviewees were asked if their organisation had a defined approach for when objectives could no longer be met. Most responses showed there was no existing approach, however two respondents specified regular updating of plans to enable an adaptive management approach. Other responses raised the need for government support and policy change to enable inclusion of adaptation, and one organisation has commenced discussions about unattainable objectives, but not developed an approach for dealing with this.

"we certainly talk about it as the organisation; whether you try and build resilience in or whether you need to actually allow it to shift to a new state. We haven't identified any values that we're going to allow transition to a different state yet. I think we're all grappling with that one."

The ways environmental water staff are currently responding to the challenge of likely unachievable objectives fall into three categories:

1. Use existing environmental water entitlements to 'buffer' the system from climate change and build resilience

2. Put efforts into securing more environmental water entitlements; some organisations are using this as an adaptation strategy and investing a lot of resources in this option. It is often organisations with highly flow stressed rivers who are considering this option.

3. Assist in helping the ecosystem transition to a new state e.g. aim to make objectives achievable over a larger spatial scale and abandon sites no longer deemed feasible, or accepting that change will happen. This option was discussed with interview participants as suggested by the following extracts: "do we start looking for other sites and maybe dropping some off the list that we don't think meet that particular objective. We might have to start reconsidering our priorities"

And from another interviewee:

"when do you let it go? People like to keep things as they are, and I think sometimes we try to keep things in the zoo. It doesn't concern me - if change happens that's what's going to happen. We've just got to identify and support it. Why are we throwing all this money, when it's naturally shifting - when do you kind of, just let it happen? I have no answer. This concerns me."

The range of respondents' opinions on this issue is quite broad, with no agreed approach or guidance from government for how or when to make decisions around an appropriate response.

Organisational responses to incorporating climate change in environmental water management also seem varied, with one organisation beginning to consider climate change but not yet referring to impacts in planning documents because they don't want to 'give up' on species or, more importantly, lose the ability to use water now and build resilience into the ecosystem. Another organisation has also started to consider impacts of climate change but is relying on the state government to decide future water availability and hence achievability of their objectives. These differing responses of both water managers and organisations show a need for large improvements in knowledge, a review of policy/planning guidelines, governance structures and the potential need for bespoke conditions due to legacy issues of past water management arrangements.

The institutional barriers to incorporating climate change adaptation are well documented for a range of climate change implications such as sea level rise (Tribbia and Moser 2008, Mozumder et al. 2011), management of national and marine parks (Jantarasami et al. 2010), and freshwater ecosystems (Barnett et al. 2015). Many of the barriers identified in this research were common to organisations around the world aiming to adapt to climate change (Eisenack et al. 2014, Ford and King 2015, Owen 2020). However, there were clear knowledge gaps and associated barriers specific to environmental water management. Despite these 
uncertainties, ecosystems still need to be managed and decisions regarding the most effective and efficient use of environmental water to achieve the desired ecological objectives are required.

\section{Conclusion}

Ecological restoration is by nature backwards looking with an aim to restore degraded or damaged environments. Yet with a future characterised by a no analogue environment i.e. one structured differently from today (Williams and Jackson 2007), water management should not only continue to look backwards, but specifically and deliberately look forwards. Our analysis highlights significant gaps in the extent to which this is occurring in Australia.

This study has exposed a desire by environmental water managers to include climate change considerations in long term planning yet there remains a clear need to update environmental flow assessment methods in Australia to ensure future hydrological scenarios and ecological conditions are included. Environmental water policy and legislation also needs updating to include consideration of a no analogue future. A review of governance would be beneficial to encourage adoption of a landscape scale which would enable easier adoption of climate change adaptations. Effective and efficient use of environmental water under climate change would benefit from increased resources and funding, and increased research and knowledge exchange. Improved knowledge needs include agreed hydrological models and scenarios, vulnerability assessments and decision support frameworks. These barriers are impacting the ability of water managers to effectively make the best use of a limited resource in a rapidly changing climate.

We have identified a range of mechanisms for the environmental water industry to improve consideration of climate change. Many of the recommended changes will require significant investment in research, institutional cross collaboration and coordination, along with legislative changes. The changes required for future management of environmental water require political courage, and recognition that water and land use changes will occur. The recommendations of this article are a first step towards making considered proactive changes to water management under climate change rather than costly, ill planned reactive decisions, or missing the opportunity to make a decision at all.

\section{Acknowledgements}

MJ is funded through an industry $\mathrm{PhD}$ position with funding from the Department of Environment, Land, Water and Planning, Victoria, Australia and Goulburn Broken Catchment Management Authority. AH was funded through an ARC DECRA award (DE180100550). 


\section{Literature cited}

ARTHINGTON, A. H., BHADURI, A., BUNN, S. E., JACKSON, S. E., THARME, R. E., TICKNER, D., YOUNG, B., ACREMAN, M., BAKER, N. \& CAPON, S. 2018. The Brisbane declaration and global action agenda on environmental flows (2018). Frontiers in Environmental Science, 6, 45.

BARNETT, J., EVANS, L. S., GROSS, C., KIEM, A. S., KINGSFORD, R. T., PALUTIKOF, J. P., PICKERING, C. M. \& SMITHERS, S. G. 2015. From barriers to limits to climate change adaptation path dependency and the speed of change. Ecology and Society, 20.

BOM \& CSIRO 2015. Climate Change in Australia - Information for Australia's Natural Resource Management Regions: Technical report. In: CSIRO; \& BOM (eds.). Canberra.

CAPON, S. J. \& CAPON, T. R. 2017. An impossible prescription: Why science cannot determine environmental water requirements for a healthy Murray-Darling Basin. Water Economics and Policy, 3, 1650037.

CHIEW, F. H. S., TENG, J., VAZE, J., POST, D. A., PERRAUD, J. M., KIRONO, D. G. C. \& VINEY, N. R. 2009. Estimating climate change impact on runoff across southeast Australia: Method, results, and implications of the modeling method. . Water Resources Research 45.

CLARKE, J., GROSE, M., THATCHER, M., HERNAMAN, V., HEADY, C., ROUND, V., RAFTER, T., TRENHAM, C. \& WILSON, L. 2019. Victorian Climate Projections 2019 Technical Report In: CSIRO (ed.). Melbourne CSIRO; State of Victoria.

DEJONCKHEERE, M. \& VAUGHN, L. M. 2019. Semistructured interviewing in primary care research: a balance of relationship and rigour. Family Medicine and Community Health, 7.

DEPARTMENT OF ENVIRONMENT, L., WATER AND PLANNING 2016. Managing extreme water shortage in Victoria - Lessons learnt from the Millennium Drought In: DEPARTMENT OF ENVIRONMENT, L., WATER AND PLANNING (ed.). Melbourne

DEPARTMENT OF ENVIRONMENT, L., WATER AND PLANNING; , METEOROLOGY;, B. O., ORGANISATION; , C. S. A. I. R. \& MELBOURNE, T. U. O. 2020. Victoria's Water in a Changing Climate. In: DELWP (ed.). Melbourne

DOOLAN, J. M., ASHWORTH, B. \& SWIREPIK, J. 2017. Planning for the active management of environmental water. Water for the Environment. Elsevier.

DUNLOP, M., PARRIS, H. \& RYAN, P. 2013. Climate-ready conservation objectives: a scoping study.

EISENACK, K., MOSER, S. C., HOFFMANN, E., KLEIN, R. J., OBERLACK, C., PECHAN, A., ROTTER, M. \& TERMEER, C. J. 2014. Explaining and overcoming barriers to climate change adaptation. Nature Climate Change, 4, 867-872.

FORD, J. D. \& KING, D. 2015. A framework for examining adaptation readiness. Mitigation and Adaptation Strategies for Global Change, 20, 505-526.

GELL, P. A., REID, M. A. \& WILBY, R. L. 2019. Management pathways for the floodplain wetlands of the southern Murray-Darling Basin: Lessons from history. River Research and Applications, 35, 1291-1301.

HART, B. T., BOND, N. R., BYRON, N., POLLINO, C. A. \& STEWARDSON, M. J. 2021. Chapter 1 Introduction to the Murray-Darling Basin system, Australia. In: HART, B. T., BOND, N. R., BYRON, N., POLLINO, C. A. \& STEWARDSON, M. J. (eds.) Murray-Darling Basin, Australia. Elsevier.

JANTARASAMI, L. C., LAWLER, J. J. \& THOMAS, C. W. 2010. Institutional barriers to climate change adaptation in US national parks and forests. Ecology and Society, 15.

JUDD, M., BOND, N. \& HORNE, A. in prep. The Challenge of setting 'climate ready' ecological targets for environmental flow planning.

KNOUFT, J. H. \& FICKLIN, D. L. 2017. The potential impacts of climate change on biodiversity in flowing freshwater systems. Annual Review of Ecology, Evolution, and Systematics, 48, 111-133.

LYNCH, A. J., THOMPSON, L. M., BEEVER, E. A., COLE, D. N., ENGMAN, A. C., HAWKINS HOFFMAN, C., JACKSON, S. T., KRABBENHOFT, T. J., LAWRENCE, D. J. \& LIMPINSEL, D. 2021. Managing for RADical ecosystem change: applying the Resist-Accept-Direct (RAD) framework. Frontiers in Ecology and the Environment.

MOZUMDER, P., FLUGMAN, E. \& RANDHIR, T. 2011. Adaptation behavior in the face of global climate change: Survey responses from experts and decision makers serving the Florida Keys. Ocean \& Coastal Management, 54, 37-44. 
O'DONNELL, E. 2017. Constructing the aquatic environment as a legal subject: legal rights, market participation, and the power of narrative. Doctor of Philosophy University of Melbourne

OWEN, G. 2020. What makes climate change adaptation effective? A systematic review of the literature. Global Environmental Change, 62, 102071.

PALMER, M. A., REIDY LIERMANN, C. A., NILSSON, C., FLÖRKE, M., ALCAMO, J., LAKE, P. S. $\&$ BOND, N. 2008. Climate change and the world's river basins: anticipating management options. Frontiers in Ecology and the Environment, 6, 81-89.

RAUNIYAR, S. P. \& POWER, S. B. 2020. The Impact of Anthropogenic Forcing and Natural Processes on Past, Present, and Future Rainfall over Victoria, Australia. Journal of Climate, 33, 8087-8106.

ROGERS, K. 2010. Floodplain Wetland Biota in the Murray-Darling Basin Water and Habitat Requirements, Melbourne, Melbourne : CSIRO Publishing.

ROLLS, R. J. \& BOND, N. R. 2017. Environmental and ecological effects of flow alteration in surface water ecosystems. Water for the Environment. Elsevier.

SAFT, M., PEEL, M. C., WESTERN, A. W. \& ZHANG, L. 2016. Predicting shifts in rainfall-runoff partitioning during multiyear drought: Roles of dry period and catchment characteristics. Water Resources Research, 52, 9290-9305.

TONKIN, Z., KING, A. J. \& MAHONEY, J. 2008. Effects of flooding on recruitment and dispersal of the Southern Pygmy Perch (Nannoperca australis) at a Murray River floodplain wetland. Ecological Management \& Restoration, 9, 196-201.

TRIBBIA, J. \& MOSER, S. C. 2008. More than information: what coastal managers need to plan for climate change. Environmental science \& policy, 11, 315-328.

WALTER, M. 2006. Social research methods, Oxford University Press.

WEST, J. M., JULIUS, S. H., KAREIVA, P., ENQUIST, C., LAWLER, J. J., PETERSEN, B., JOHNSON, A. E. \& SHAW, M. R. 2009. US natural resources and climate change: concepts and approaches for management adaptation. Environmental management, 44, 1001.

WILLIAMS, J. W. \& JACKSON, S. T. 2007. Novel climates, no-analog communities, and ecological surprises. Frontiers in Ecology the Environment, 5, 475-482. 
Table 1: Consequences of climate change to general catchment and environmental water use

\section{Direct consequence}

Reduced overall water availability and increased competition for water use

Shifting seasonal rainfall patterns may result in conflicting water availability and patterns of demand (e.g. high demand in spring, but lower rainfall)

Increased groundwater use

Increased farm dams

Risk of not achieving ecological outcomes due to acute heat days and species stress

Implications for environmental water management

Need for increased coordination of environmental water agencies

Increased scrutiny on how environmental water is used

Increased pressure to provide community benefits rather than purely ecological outcomes

Need to investigate all irrigation viability

Environmental water management moving from a well-known 'plan and deliver' cycle to crisis response (e.g. fish kill management)

Increased requirement for environmental water managers to trade off sites against each other --> further

tension within a basin scale

Socio-economic impacts when rivers stop or change flow regime

Table 2: Incorporation of climate change considerations in respondent's decision making or planning (based on survey)

\begin{tabular}{|c|c|c|c|c|}
\hline & Always & Often & Sometimes & Rarely \\
\hline Survey responses & 6 & 9 & 13 & 4 \\
\hline
\end{tabular}

Table 3: Suggested changes to overcome barriers identified by this research

Barrier $\quad$ Change required

Knowledge

Uncertainty how ecosystems will respond

Not knowing how or where to start

Availability of useable, local information scenario to choose

Siloed approach to environmental water management

Policy/legislation

Current legislation doesn't consider climate change

Legacy land use and water sharing arrangements
- Continue funding research into changing hydrology and rainfall runoff relationships

- Continue funding research into ecological response to predicted hydrologic and ecosystem changes

- $\quad$ Provide funding for more vulnerability assessments

- Improve knowledge exchange between science and managers/end user fund knowledge brokers

- State governments to provide guidance to environmental water managers in a specific, easy to use format

- Work with local scientific organisations (e.g. CSIRO) to downscale global and national climate and flow forecasts to a local scale

- Be clear with the limit of confidence and error margin in these downscaled results

- $\quad$ Provide guidance to managers/end users on assessing and planning for a range of scenarios rather than just one

- Improve knowledge exchange between science and managers/end user of climate scenarios and how to prepare robust plans

- State governments to provide guidance to environmental water managers in a specific, easy to use format

- Improved knowledge sharing and integration with complementary river health works

- Need for legislative change through parliament and international treaty agreements

- Review all water use throughout the country and make policy decisions on the best place and use of water

- Government to assist community and industry transition to new enterprises where required (e.g. dryland farming)

Will need to be addressed on a case by case basis - but aim for consistency where possible 


\begin{tabular}{|c|c|}
\hline \multicolumn{2}{|l|}{ Planning and monitoring } \\
\hline $\begin{array}{l}\text { Planning occurs predominantly on an } \\
\text { annual time scale }\end{array}$ & $\begin{array}{l}\text { - Requirements from water entitlement holders and delivery partners to } \\
\text { plan on an annual and } 5 \text { yearly and longer time frame. } \\
\text { Ensure these plans reflect local and basin wide goals - if there is a conflict, } \\
\text { ensure resolution of objectives for the most effective use of water for } \\
\text { ecological benefit }\end{array}$ \\
\hline Planning occurs on a single river basis & $\begin{array}{l}\text { - Change setting ecological objectives from a single river system to } \\
\text { broader basin scale objectives } \\
\text { - Inclusion of operational restrictions when setting long term ecological } \\
\text { objectives }\end{array}$ \\
\hline $\begin{array}{l}\text { Lack of monitoring information for } \\
\text { adaptive management }\end{array}$ & $\begin{array}{l}\text { - Improved auditing and monitoring of environmental water deliveries } \\
\text { against ecological objectives } \\
\text { - Ensure monitoring is appropriate for adaptative management decisions } \\
\text { and to identify tipping points }\end{array}$ \\
\hline \multicolumn{2}{|r|}{ 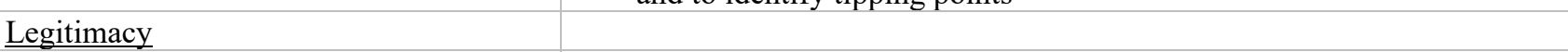 } \\
\hline $\begin{array}{l}\text { Lack of confidence from managers in } \\
\text { climate and hydrology predictions }\end{array}$ & $\begin{array}{l}\text { - Encourage greater collaboration between researchers and end users - } \\
\text { fund knowledge brokers } \\
\text { - Improve communication of confidence limits of predictions from } \\
\text { science predictions }\end{array}$ \\
\hline Lack of public support & $\begin{array}{l}\text { Improved communication of the benefits derived from environmental } \\
\text { water - both ecological, but also ecosystem services, economic and } \\
\text { social benefits } \\
\text { - Fund more regionally located communication officers who are members } \\
\text { of local communities }\end{array}$ \\
\hline \multicolumn{2}{|l|}{ Political / governance } \\
\hline Lack of political leadership & - Remove politics from the science of river health and water management \\
\hline $\begin{array}{l}\text { Conflicting objectives for organisations } \\
\text { managing water }\end{array}$ & - Review organisational responsibilities and objectives \\
\hline Current water governance arrangements & $\begin{array}{l}\text { - Review organisational responsibilities } \\
\text { - Decide on the most efficient scale and administration to manage } \\
\text { environmental water in a changing world } \\
\text { - Encourage state governments to take a larger role in trade off and } \\
\text { decision making in terms of water use }\end{array}$ \\
\hline Lack of staff and funding & $\begin{array}{l}\text { - Fund specific climate adaptation roles in regional organisations } \\
\text { - Fund knowledge broker roles in state and commonwealth agencies }\end{array}$ \\
\hline
\end{tabular}




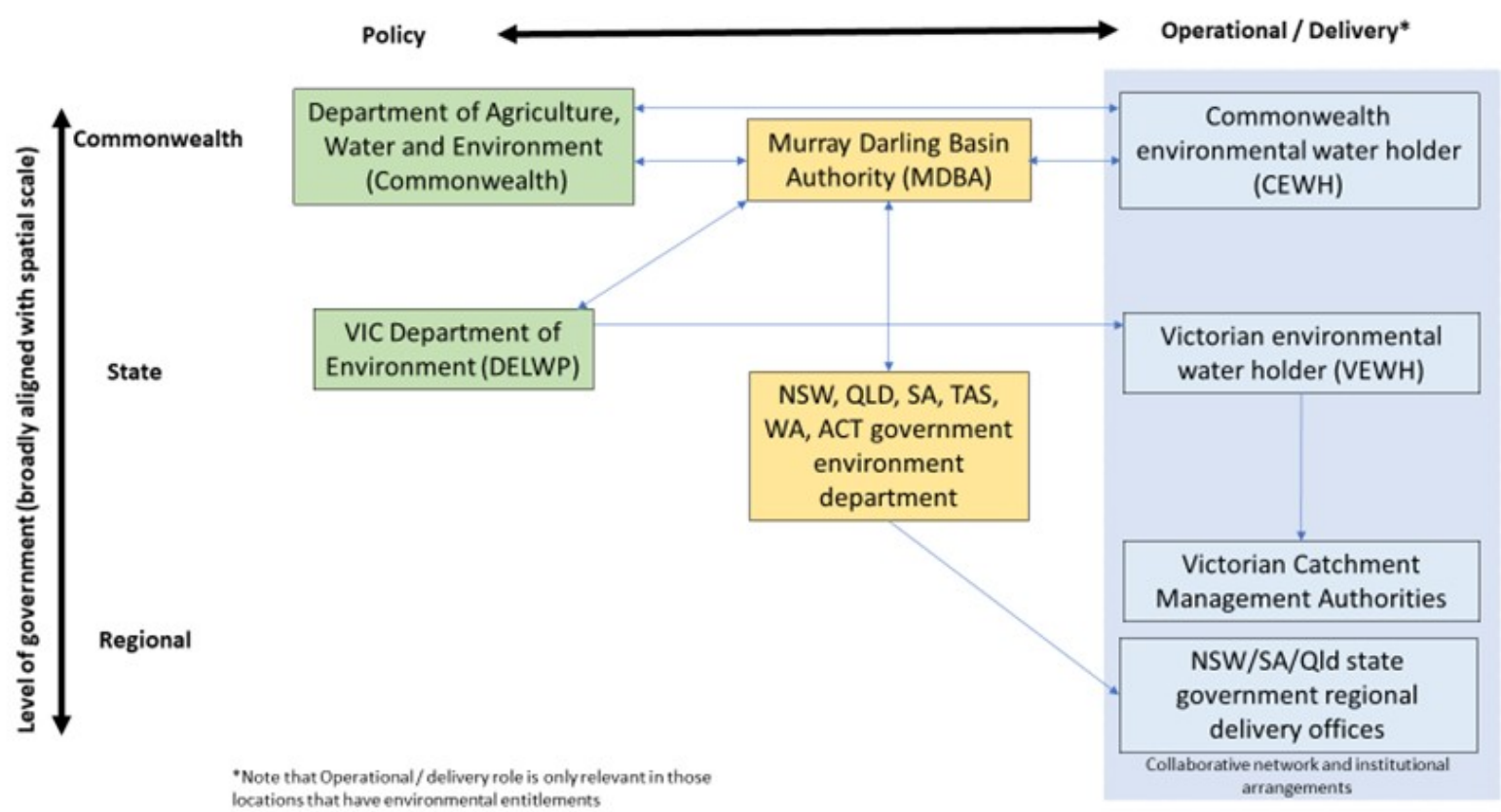

Figure 1: Arrangement of different levels of governance of environmental water management in Australia. Beneath Commonwealth level of governance, water management is guided by state legislation and results in states and territories having differing levels of governance. Green indicates a policy organisation, yellow indicates a policy and operational organisation and blue represents an operational organisation. This figure focuses on government organisations and acknowledges traditional owner and not for profit organisations are not represented

Ability of environment to sustain current values

More intense and frequent droughts

Less run off

Increased competition for water use

Reduced frequency/extent of floodplain inundation

Species extinction

Increased heatwave days

Shifting seasonality of rain

Reduced water quality

Altered temperatures affecting migration/breeding cues

Increased groundwater use

Disruption of food webs

Transition to a new ecosystem type

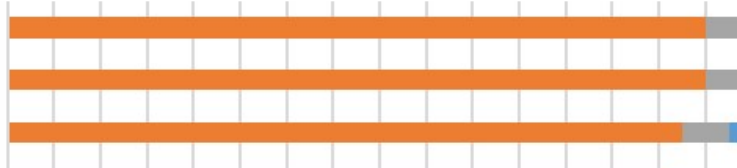

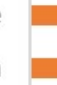

Ting

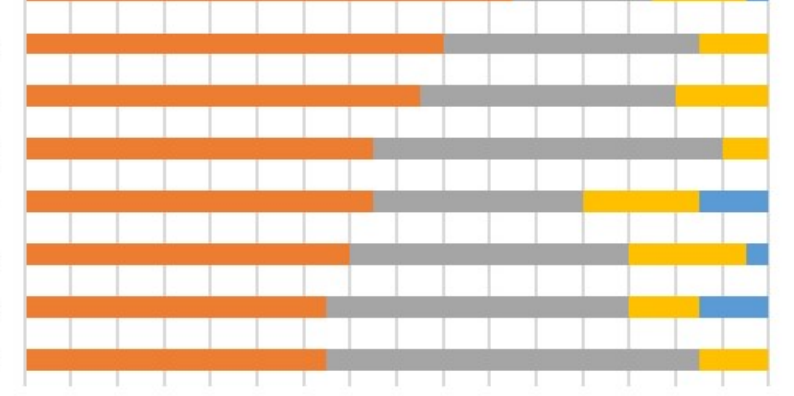
$\begin{array}{llllllllllllllllll}0 & 2 & 4 & 6 & 8 & 10 & 12 & 14 & 16 & 18 & 20 & 22 & 24 & 26 & 28 & 30 & 32 & 34\end{array}$ Number of survey participants

$$
\text { - } \quad \text { High Medium } \quad \text { Low Unsure }
$$

Figure 2: Level of concern from water managers around climate change impacts on their local catchments and management of environmental water. (survey results only). 


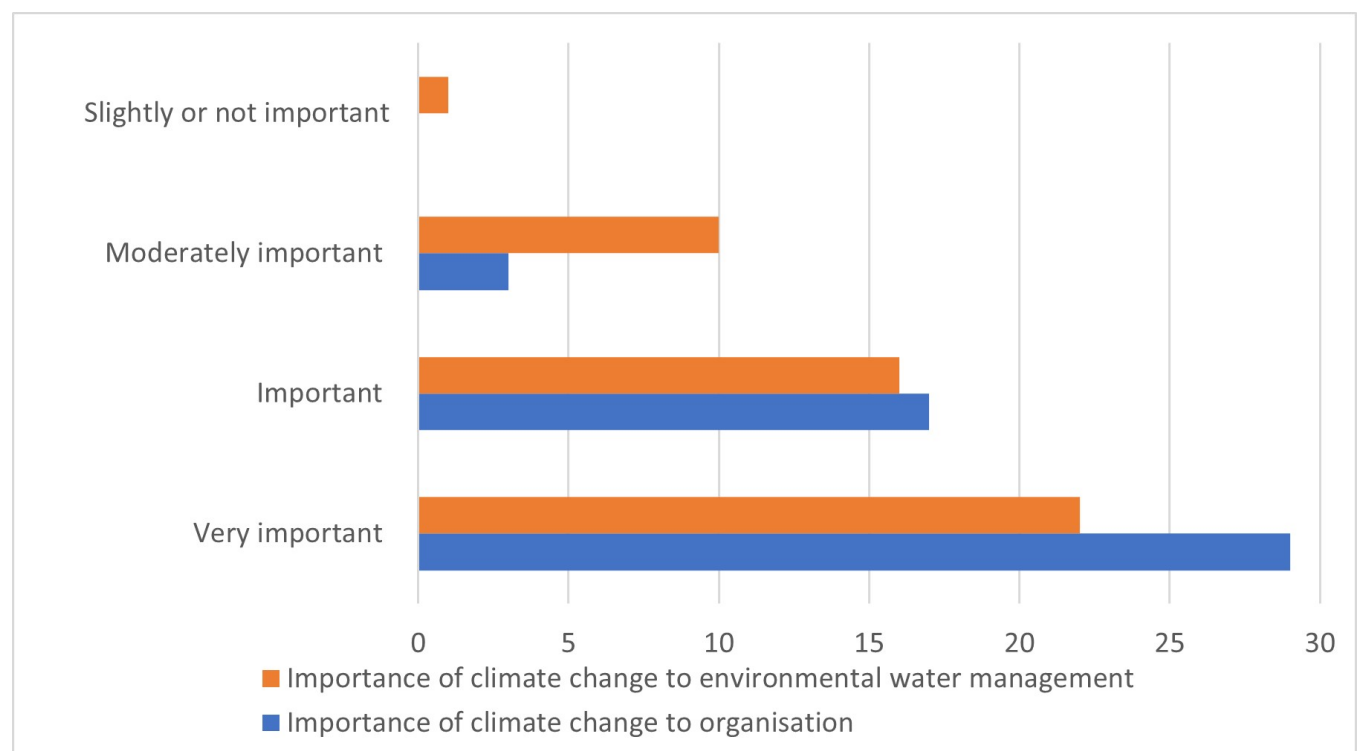

Figure 3: Combined results from the interviews and online survey regarding the importance of climate change to the organisation, and more specifically the importance of climate change to environmental water management in their organisation.

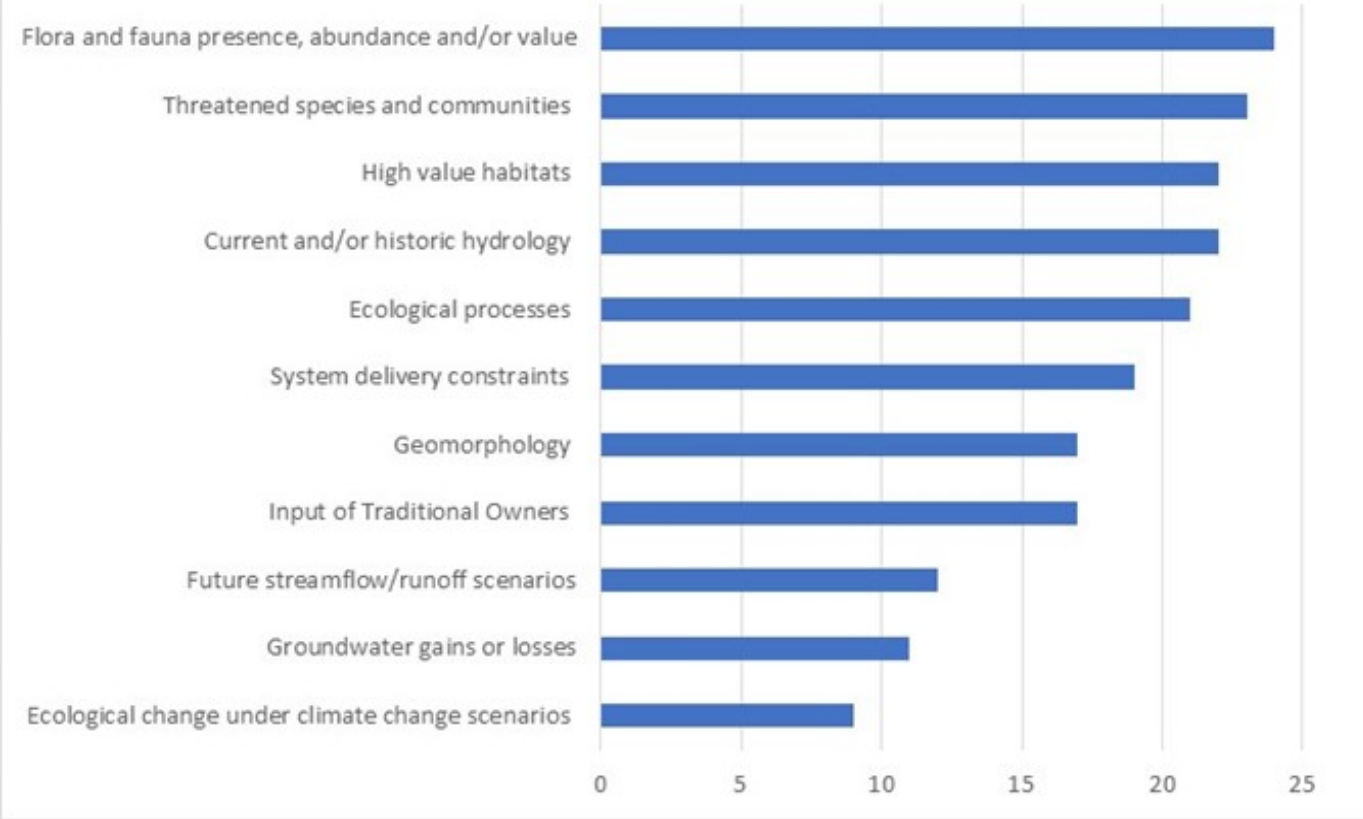

Figure 4: Issues considered by organisations when setting ecological flow objectives (survey results only) 
Insufficient funding and staff resources

Uncertainty around how ecosystems will respond to climate change

Lack of political leadership - any level of government

Legacy land use and water sharing issues*

Not knowing how or where to start

Current water governance arrangements*

Lack of clarity around which organisation is responsible

Lack of confidence in climate change forecasts

Lack of public support for addressing climate change

Conflicting objectives of environmental water organisations

Lack of confidence in rainfall/run off predictions*

Current legislation doesn't consider climate change*

Availability of useable, local information^

Uncertainty about which climate change scenario to choose*

Lack of will in your organisation
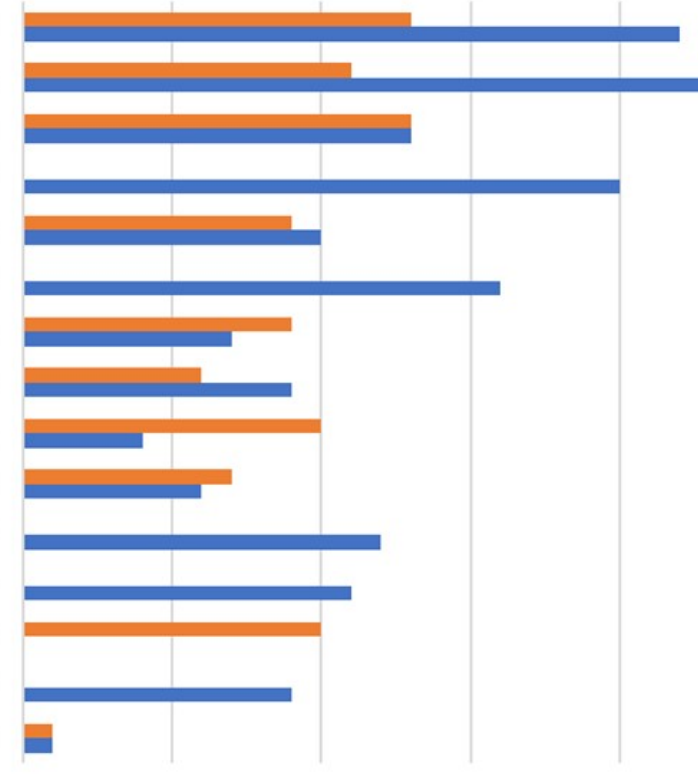

0

10

20

25

Interview Online survey

Figure 5: Barriers to incorporation of climate change from survey and interview results.

$*$ question asked in survey only ${ }^{\wedge}$ question asked in interviews only 


\section{Appendix 1}

\section{Interview Guide}

Clarification: For these interviews, the definition of an ecological objective is a desired long term ecological outcome that delivery of e-water is aiming to achieve (e.g. increase the abundance and age class of native fish).

This differentiates from a flow recommendation or hydrological objective which is the hydrological requirement to meet the ecological objective (e.g. a spring fresh of certain magnitude and duration)

\section{A. Participant's and organisation's role}

1. What is your organisation's role in the management of environmental water?

2. Can you describe your role in e-water management? Are you executive, manager, officer level?

3. How long have you worked in environmental water management?

4. Are you involved in short term operational decisions or longer term strategic decisions, or both?

\section{B. Current objective setting process and decision making (inputs, information sources, $\underline{\text { timeframes) }}$}

5. How does your organisation determine long term flow objectives? e.g. is there a particular method or process you use?

Prompts: e.g. Victorian FLOWS/EWMP method

6. Have you been involved in setting long term flow objectives?

7. Other than your organisation, who else provides inputs to these objectives? (what kinds of information do they contribute?)

\begin{tabular}{|l|l|}
\hline \multicolumn{2}{|c|}{ Tick } \\
\hline Scientists - researchers, consultants & \\
\hline Resource/water manager & \\
\hline Other government departments & \\
\hline Community & \\
\hline Indigenous community & \\
\hline Others & \\
\hline
\end{tabular}

7B. Do you think any of these groups have more influence than others?

Can you list them in order of most influential to least influential?

What are the reasons for the differences in influence?

8. When developing objectives, are you aware of efforts to link to other strategies of your organisation, or state or commonwealth agencies? e.g. waterway strategy, BP Env Watering strategy

Which ones?

If no, why not.

9. When ecological objectives were set, do you know what kind of information was considered?

9A. Was information on future water availability considered (i.e. $20+$ yr time frame)?

If yes, where did this information come from?

Do you know whether the inclusion of that information (if it occurred) altered the suite of objectives?

10. Is there an explicit timeframe over which your organisation (or method) sets e-flow objectives for? Yes/no. If so, how long?5, 10, 20 years? Any longer? 
11. Do these timeframes allow you to consider long term outlooks of climate and ecology? (e.g. long lived fish or veg spp - up to 50yr)? Would longer timeframes change your objectives? How?

12. How do you consider your long term objectives when setting annual priority watering actions?

13. Do you consider spatial scale when setting your objectives?

How do you negotiate objectives both in your catchment with those in the wider basin?

14. [FOR THE WATER HOLDERS ONLY]

Has there been a time when annual priorities (of basin states) did not focus on long term or BP objectives?

If yes, when has this occurred and how did you deal with this?

\section{Planning for the future - specifically climate change (timeframe - next 20 - 30yrs)}

15. How much would you say your organisation considers climate change an issue?

$1=$ not important $\quad 2=$ slightly important $\quad 3=$ moderately important $\quad 4=$ very

important

16. Does your organisation consider climate change as issue for environmental water management? (yes/no)

$1=$ not important $\quad 2=$ slightly important $\quad 3=$ moderately important $\quad 4=$ very

important

17. How do you think climate change could impact river health and e-water management?

18. From the literature I have gathered a list of climate change impacts to aquatic ecosystems.

Can you rank how important you think the following impacts will be in your catchment?

\begin{tabular}{|l|l|l|l|l|l|}
\hline & Not important & $\begin{array}{l}\text { Slightly } \\
\text { important }\end{array}$ & $\begin{array}{l}\text { Moderately } \\
\text { Important }\end{array}$ & Important & $\begin{array}{l}\text { Very } \\
\text { important }\end{array}$ \\
\hline $\begin{array}{l}\text { More frequent and longer } \\
\text { droughts }\end{array}$ & & & & & \\
\hline Altered seasonality of rainfall & & & & & \\
\hline Increased blackwater events & & & & & \\
\hline $\begin{array}{l}\text { Increased fire frequency and } \\
\text { severity }\end{array}$ & & & & & \\
\hline $\begin{array}{l}\text { Reduced frequency and extent of } \\
\text { floodplain inundation }\end{array}$ & & & & & \\
\hline $\begin{array}{l}\text { Increased water temperature and } \\
\text { pressure on spp thermal } \\
\text { tolerances } \rightarrow \text { range shifts }\end{array}$ & & & & & \\
\hline $\begin{array}{l}\text { Altered life cycle cues for many } \\
\text { species }\end{array}$ & & & & & \\
\hline Disruption of food webs & & & & & \\
\hline Increased invasive spp & & & & & \\
\hline
\end{tabular}

19. Can you rank which issues around climate change and e-water are you most concerned about? (20-30 year timeframe)

\begin{tabular}{|l|l|l|l|l|l|}
\hline & Not at all & $\begin{array}{l}\text { Slight } \\
\text { concern }\end{array}$ & $\begin{array}{l}\text { Moderate } \\
\text { concern }\end{array}$ & $\begin{array}{l}\text { High } \\
\text { concern }\end{array}$ & $\begin{array}{l}\text { Very high } \\
\text { concern }\end{array}$ \\
\hline Water availability & & & & & \\
\hline Water quality & & & & & \\
\hline $\begin{array}{l}\text { Suitability of environment to } \\
\text { sustain current values }\end{array}$ & & & & & \\
\hline Species range shifts & & & & & \\
\hline Species extinction & & & & & \\
\hline
\end{tabular}




\begin{tabular}{|l|l|l|l|l|l|}
\hline $\begin{array}{l}\text { Changing structure of food } \\
\text { webs }\end{array}$ & & & & & \\
\hline $\begin{array}{l}\text { Overall ecosystem } \\
\text { transformation }\end{array}$ & & & & & \\
\hline Other & & & & & \\
\hline
\end{tabular}

20. Can you think of ways that climate change could be included in e-flow planning? If yes, provide e.g.

21. Do you think incorporating climate change scenarios into planning would change your organisation's objectives?

If yes, how? (e.g. prioritise one site over another, timeframe of achieving objectives)

22. A vulnerability assessment looks at the pressures that climate change will have on a particular species or taxonomic group by assessing their sensitivity, exposure and capacity to adapt to the predicted change, such as potential range and habitat changes and extinction probabilities.

Do you think incorporating species vulnerability assessments into planning would change your objectives?

23. Is it feasible for your organisation to undertake such assessments in planning for environmental water (CC scenarios and vulnerability assessment)?

\section{Adaptation and barriers to planning for the future}

24. Are you and your team aware if your organisation has a climate adaptation plan?

25. Are you and your team aware of adaptations that could be incorporated into e-water plans or objectives to manage for CC? e.g. protection of refuges, provision of habitat corridors, allow non locally native spp to establish, maintain ecosystem function rather than specific species, translocation

26. Are any of these issues incorporated in management plans and objectives? [if no, go to Q27] If yes - how are you doing this and what information are you using (e.g. climate scenarios, vulnerability assessments, habitat mapping)?

27. If climate change considerations are not being incorporated into e-water mgt by your organisation, why do you think this might not be the case?

28. What do you think your organisation needs to be able to include climate change adaptations to ewater planning?

29. Would additional information or a different information format from what you currently have, help to incorporate climate change into e-water mgt?

30. From the literature, I have gathered a list of barriers to incorporation of climate change adaptations for different organisations. In addition to the issues you listed in the previous questions, can you also consider the relevance of the following?

\begin{tabular}{|l|l|}
\hline & Relevant (Y/N) \\
\hline Uncertainty of climate change predictions & \\
\hline Uncertainty of ecological response to climate change & \\
\hline Not knowing how or where to start & \\
\hline Availability of useable (including local) information & \\
\hline Insufficient funding for adaptation & \\
\hline Lack of clarity around what organisation responsible & \\
\hline Conflicting objectives of organisations managing e-water & \\
\hline Institutional/organisation unwillingness & \\
\hline Lack of political leadership & \\
\hline
\end{tabular}


31. Given the impacts of climate change do you think it will be possible for your organisation to maintain the full suite of existing environmental objectives in the future?

[Yes Not sure $\quad$ No]

If no, why not? Water availability, or other factors? (e.g. if you assumed you could acquire more water would it solve the problem?)

32. Does your organisation have an approach for deciding how to deal with unachievable objectives? If yes, can you please describe this approach. E.g. revise objectives regularly, incorporate climate scenarios into planning, allow non local spp to establish, focus on ecosystem services rather than purely ecological integrity [adaptation, transformation]

33. Do you think there is a better way to develop objectives in light of future climate change challenges (e.g. incorporate climate change scenarios into planning, use Long term water resource plans, carry out species vulnerability assessments)?

If so, please provide detail

34. Is there anything else you would like to add? 


\section{Appendix 2}

\section{$\underline{\text { Online survey questions }}$}

1. What state or territory are you located in for your work?

- ACT

- NSW

- NT

- QLD

- SA

- VIC

- WA

2. What type of organisation do you work for?

- Local government

- State government authority

- Regional arm of state government

- State government

- Commonwealth government

- Not for profit

- Other

3. What level is your current role in environmental water management:

- Executive level

- Director

- Manager level

- Officer/coordinator level

- Other - please specify

4. How long have you worked in environmental water management?

- $0-4$ years

- 5 - 9 years

- 10 - 15 years

- $16-20$ years

- Longer than 20 years

5. In what capacity are you mostly (i.e. more than $50 \%$ of your time) involved in environmental water management decisions? (tick one)

- Strategic / policy

- Operational

- Both strategic and operational

- Other - please provide details

6. As part of your current role, do you incorporate climate change considerations in your decision making or planning?

$1=$ never

$2=$ rarely

$3=$ sometimes

$4=$ often

$5=$ always

7. Do you think incorporating climate change considerations is important in your current role?
a. Yes - why?

b. No - why not? 
8. Please indicate the level of your concern around the following issues specifically related to climate change and environmental water management:

\begin{tabular}{|l|l|l|l|l|}
\hline & Low & Medium & High & Unsure \\
\hline Less run off & & & & \\
\hline Reduced water quality & & & & \\
\hline Shifting seasonality of rainfall & & & & \\
\hline Increased heatwave days & & & & \\
\hline More intense and frequent droughts & & & & \\
\hline $\begin{array}{l}\text { Altered air and water temperatures impacting cues for } \\
\text { migration and breeding }\end{array}$ & & & & \\
\hline Species extinction & & & & \\
\hline Disruption of food webs & & & & \\
\hline Reduced frequency and extent of floodplain inundation & & & & \\
\hline Increased groundwater use & & & & \\
\hline $\begin{array}{l}\text { Increased overall competition for water (including } \\
\text { consumptive) }\end{array}$ & & & & \\
\hline Ability of environment to sustain current values & & & & \\
\hline Transition of the environment to a new ecosystem type & & & & \\
\hline
\end{tabular}

9. How important is climate change is to your organisation?

$$
\begin{aligned}
& 1=\text { not important } \\
& 2=\text { moderately important } \\
& 3=\text { important } \\
& 4=\text { very important }
\end{aligned}
$$

10. How important does your organisation consider climate change for environmental water management?

$$
\begin{aligned}
& 1=\text { not important } \\
& 2=\text { moderately important } \\
& 3=\text { important } \\
& 4=\text { very important }
\end{aligned}
$$

If climate change is less considered less important for environmental water management than other areas, please explain?

11. Is your organisation responsible for establishing long term environmental flow objectives?

- Yes

- No (go to question 17)

12. What is the timeframe for environmental flow objectives set by your organisation?

- No timeframe

- $0-10$ years

- $11-20$ years

- Longer than 20 years

- Other (please specify)

13. Do you think current timeframes allow you to consider long term outlooks of climate and ecology?

- Yes

- No

If no, please explain:

14. Can you tick which factors are considered when setting long term ecological objectives? 


\begin{tabular}{|l|l|}
\hline Flora and fauna presence, abundance and/or value & \\
\hline High value habitats & \\
\hline Threatened species and communities & \\
\hline Geomorphology & \\
\hline Ecological processes & \\
\hline Current and/or historic hydrology & \\
\hline Groundwater gains or losses & \\
\hline Knowledge/ input of Traditional Owners and custodians of the land & \\
\hline System delivery constraints & \\
\hline Future streamflow/runoff scenarios & \\
\hline Future ecological change under climate change scenarios & \\
\hline Others - please specify: & \\
\hline
\end{tabular}

15. If you used future climate change related streamflow/runoff scenarios or ecological change predictions, what was the source of your information?

Did the inclusion of future climate/ runoff scenarios and ecological change predictions alter the objectives adopted in your plan? Yes/no

16. If you did not use future streamflow/runoff scenarios or ecological change predictions, why not?

17. Do you think your local community would be supportive of changing the ecological objectives to incorporate climate change considerations?

18. Rate your agreement with the following statement; "there is ample information on the ecological response to climate change to inform environmental water planning"

- Strongly disagree

- Disagree

- Agree

- Strongly agree

- Undecided

19. Has your organisation drawn on knowledge of Traditional Owners and Custodians of the land when considering climate change impacts in environmental water management?

- Yes. If yes, how?

- No

20. If climate change considerations are not being incorporated into environmental water management by your organisation, why do you think this is the case?

21. The following are general barriers to incorporating climate change in natural resource management. Can you indicate which of these are relevant barriers in the management of environmental water and climate change for your organisation?

\begin{tabular}{|l|l|}
\hline & $\begin{array}{c}\text { Relevant } \\
\text { (Yes/No) }\end{array}$ \\
\hline Lack of confidence in climate change forecasts & \\
\hline Uncertainty about which climate change scenario to choose for planning & \\
\hline Lack of confidence in future rainfall/run off predictions & \\
\hline Uncertainty around how ecosystems will respond to climate change & \\
\hline Not knowing how or where to start & \\
\hline Insufficient funding and staff resource & \\
\hline Current water governance arrangements & \\
\hline Lack of clarity around which organisation is responsible & \\
\hline
\end{tabular}




\begin{tabular}{|l|l|}
\hline Conflicting objectives of organisations managing environmental water & \\
\hline Lack of will in your organisation & \\
\hline Current legislation doesn't consider climate change & \\
\hline Lack of political leadership - any level of government & \\
\hline Lack of public support for commencing to adapt to climate change & \\
\hline Legacy land use and water sharing issues & \\
\hline
\end{tabular}

22. Rate your agreement with the following statement; "Current operational delivery restrictions limit the ability to incorporate climate change adaptations actions in environmental water management?"

- Strongly disagree

- Disagree

- Undecided

- Agree

- Strongly agree

23. What operational restrictions would you change to enable greater incorporation and action on climate adaptation?

24. A species vulnerability assessment looks at the pressures that climate change will have on a particular species or taxonomic group by assessing their sensitivity, exposure and capacity to adapt to the predicted change, such as potential range and habitat changes and extinction probabilities.

Has your organisation previously undertaken species vulnerability assessments in planning?

Do you think incorporating species vulnerability assessments into planning would change your objectives?

- Yes

- No

- Not sure

25. What do you think is needed to enable inclusion of climate change considerations and adaptations more readily into environmental water planning? (choose your top 5)

\begin{tabular}{|l|l|}
\hline Fit for purpose and consistent region-wide hydrological models & \\
\hline Species/community vulnerability assessments & \\
\hline $\begin{array}{l}\text { Quantified ecosystem response models to predicted scenarios of } \\
\text { hydrology/temperature change }\end{array}$ & \\
\hline $\begin{array}{l}\text { A flow assessment method that incorporates future climate and hydrological } \\
\text { scenarios }\end{array}$ & \\
\hline More frequent updates of flows studies and long term planning documents & \\
\hline Change in setting site based objectives to landscape scale objectives & \\
\hline $\begin{array}{l}\text { A shift in environmental water management from largely annual planning to longer } \\
\text { term }\end{array}$ & \\
\hline Removal of delivery constraints where appropriate & \\
\hline Increased monitoring of environmental water delivery & \\
\hline Greater investment in research of climate change and environmental water & \\
\hline Improved knowledge exchange between applied research and industry & \\
\hline $\begin{array}{l}\text { Tools and information/framework to guide decision making under uncertain } \\
\text { circumstance (e.g. adaptation pathways) }\end{array}$ & \\
\hline Working with economists to put a value ecosystem values & \\
\hline Improved integration with complementary river health works & \\
\hline Other (please specify) & \\
\hline
\end{tabular}

26. Who should be taking the lead on providing guidance for inclusion of climate change scenarios and adaptation in environmental water?

○ (tick the most appropriate) 
- Commonwealth environmental water holder

- Murray Darling Basin Authority

- State environmental water holder/agency

- Other state environmental department

- Regional authorities

- Collaboration at all levels of environmental water management

- Each organisation should do their own planning

- Other; please specify

27. What type of actions would you consider for your catchment to address climate change issues: (tick all that apply)

Commence discussions with community on changing environment and then need to change objectives

Purchase/reallocate more water for the environment

Invest in infrastructure for watering

Review water trading and storage rules

Prioritise sites and decide to 'let some go'

Deliver water to maintain ecosystem functions rather than specific species, even if this means watering for non locally indigenous species

Build habitats, including refuges and habitat corridors

Remove barriers to movement of species

Improve riparian and wetland vegetation cover, including species from different climatic zones

Actively promote ecosystem transformation e.g. translocating species, encouraging wetlands to modify to a different type

Stock river systems with farm bred fish instead of delivering flows to promote spawning

Revise ecological objectives to include future climate and flow scenarios

Look at a landscape scale approach to achieving objectives outside your current management area

Other (please specify)

28. Given the impacts of climate change do you think it will be possible for your organisation to maintain the full suite of existing environmental objectives in the future within the bounds of current policy?

- Yes

- Not sure

- No

If no, why not? Are there particular policy settings or water sharing arrangements you would petition to change?

29. Which approach(es) does your organisation currently have for future objective setting with respect to climate change? (tick as many as apply)

- Regularly revise objectives

- Incorporate climate change and run off scenarios into planning

- Incorporate vulnerability assessments into planning

- Stress test existing objectives under climate change scenario modelling to see when they are no longer achievable

- Invest in a knowledge broker to connect research and applied management

- Investigate and fund a multiple option style approach for planning and decision making (e.g. plan for a range of future scenarios rather than just one future)

- Work with government to change policy (e.g. ensuring return flows occur on all applicable deliveries, find alternate water source for consumptive use) 
- Start conversations with local communities about future feasibility of the current ecosystem

- Other (please provide detail)

- No approach at present

Thank you for participating and sharing your perspectives. Your response to this survey will help advance understanding of climate change inclusions in environmental water management. 